\title{
Diaphragmatic hernia in a sheep - a case report
}

\author{
Aynur Simsek $^{1 *}$, Turan Yaman ${ }^{2}$, Hasan Icen ${ }^{1}$, and Akin Kochan ${ }^{1}$ \\ ${ }^{1}$ Department of Internal Diseases, Faculty of Veterinary Medicine, University of Dicle, Diyarbakir, Turkey \\ ${ }^{2}$ Department of Pathology, Faculty of Veterinary Medicine, University of Yuzuncu Yil, Van, Turkey
}

SIMSEK, A., T. YAMAN, H. ICEN, A. KOCHAN: Diaphragmatic hernia in a sheep - a case report. Vet. arhiv 88, 271-277, 2018.

\section{ABSTRACT}

A two-year-old sheep was referred to the clinics of the Department of Internal Medicine of Dicle University, Faculty of Veterinary Medicine, with signs of anorexia, abdominal tympany and constipation. The clinical examination of the animal revealed the presence of respiratory failure associated with weaker lung sounds on the right side of the body when compared to the left side. There were no ruminal movements, and when the rumen was probed with a stomach tube, no ruminal content was obtained. The animal was euthanized upon the request of the owner, and a necropsy was performed. At necropsy, it was observed that the left hepatic lobe had protruded into the thoracic cavity through a defect in the diaphragm, and that a diaphragmatic hernia had developed.

Key words: constipation; hernia diaphragmatica; liver; respiratory failure; sheep; trauma

\section{Introduction}

Diaphragmatic hernia is described as the protrusion of one or more abdominal organs into the thoracic cavity through a congenital or acquired opening in the diaphragm (IMREN and SAHAL, 1996). While cases of congenital diaphragmatic hernia occur as a result of congenital defects of the diaphragm, acquired cases develop as a consequence of traffic accidents, falls from height, blunt traumas (KORKMAZ et al., 2010), dystocia and traumatic reticuloperitonitis (RADOSTITS et al., 2007). The condition is common in cats and dogs (IMREN and SAHAL, 1996), but it is observed occasionally in small ruminants, including sheep and goats (NARAYANAN et al., 2014). Clinical findings are dyspnoea, bilateral asymmetric lung sounds (NARAYANAN et al., 2014), anorexia, tachycardia, slightly increased body temperature, intestinal sounds upon the auscultation of the thorax, and constipation (IMREN and SAHAL, 1996). Diagnosis is based on

\footnotetext{
${ }^{*}$ Corresponding author:

Dr. Aynur Simsek, Department of Internal Diseases, Faculty of Veterinary Medicine, University of Dicle, 21180, Diyarbakir, Turkey, Phone: +90 412248 8020; E-mail: asimsek@dicle.edu.tr
} 
radiography, ultrasonography, laparotomy or post-mortem examination (ZUSATZ et al., 2005; SABEV and KANAKOV, 2009).

Researchers have reported the herniation of several organs in ruminants, including the forestomach (BELLAVANCE et al., 2010; NARAYANAN et al., 2014), abomasum (BUSIN et al., 2013; WILLIAMS et al., 2016), intestines (TAFTI, 1998; NARAYANAN et al., 2014), spleen, liver and gall bladder (NARAYANAN et al., 2014).

To the authors' knowledge, literature reports on cases of diaphragmatic hernia in sheep are scarce, and the available reports lack detailed examination findings of traumatic cases. Furthermore, no case presentation from Turkey, including ante-mortem examination, has been published before. In this case report, we describe the clinical, haematological, biochemical and necropsy findings related to diaphragmatic hernia in a sheep.

\section{Case presentation}

A two-year-old sheep was referred to the clinics of the Department of Internal Medicine of Dicle University, Faculty of Veterinary Medicine, with signs of anorexia, abdominal tympany and constipation.

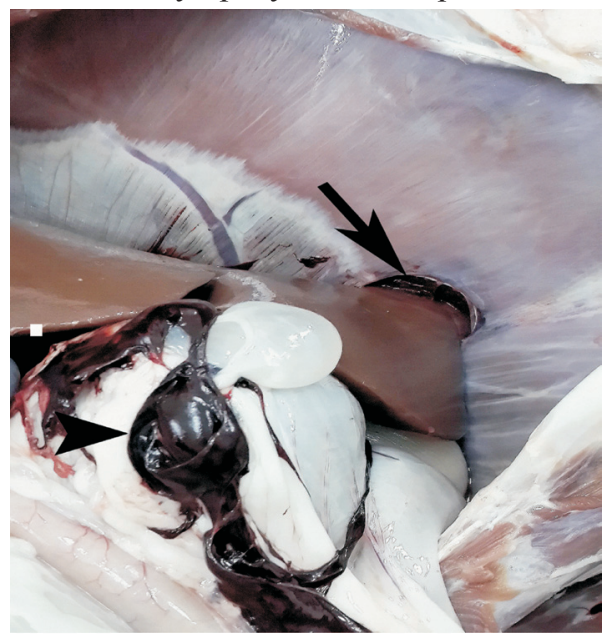

Fig. 1. The herniation of the liver into the thoracic cavity through an opening in the diaphragm (arrow) and coagulated blood (arrowhead)

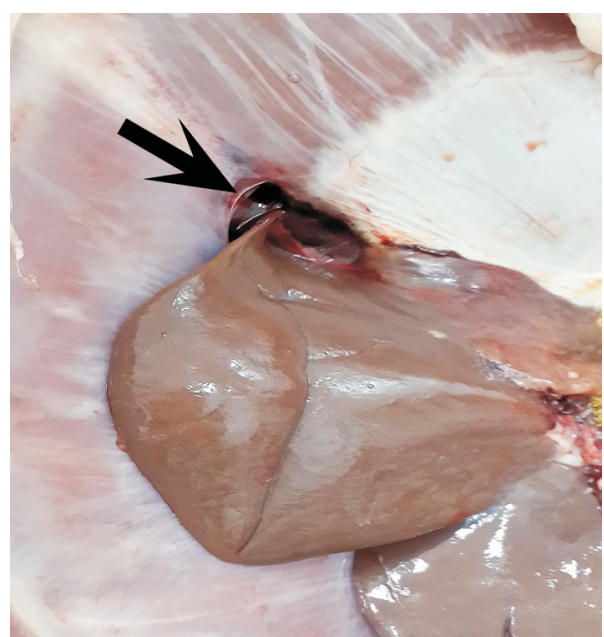

Fig. 2. The herniation of the liver into the thoracic cavity through an opening in the diaphragm (arrow), caudoventral view

The clinical examination of the animal revealed the presence of respiratory failure associated with weaker lung sounds on the right side of the body when compared to the 
left side. The respiratory rate, pulse frequency and body temperature were recorded as 39 breaths $/ \mathrm{min}, 111$ beats $/ \mathrm{min}$, and $41.2{ }^{\circ} \mathrm{C}$, respectively. There were no ruminal movements, and when the rumen was probed with a stomach tube, no ruminal content was obtained.

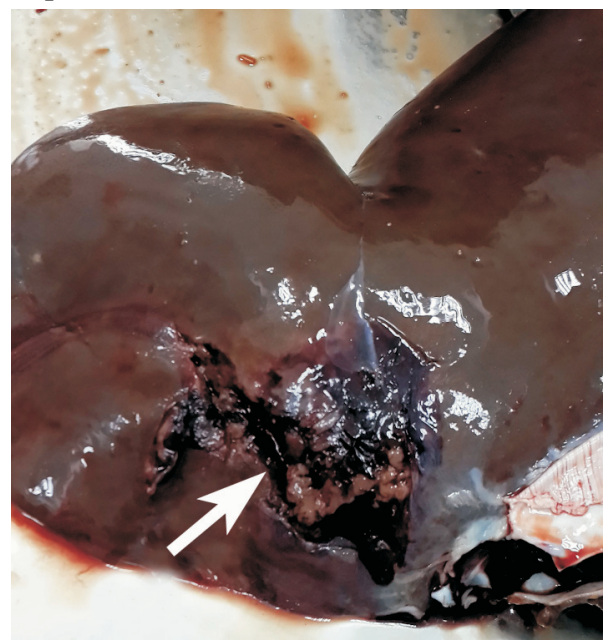

Fig. 3. Rupture of the liver (arrow)

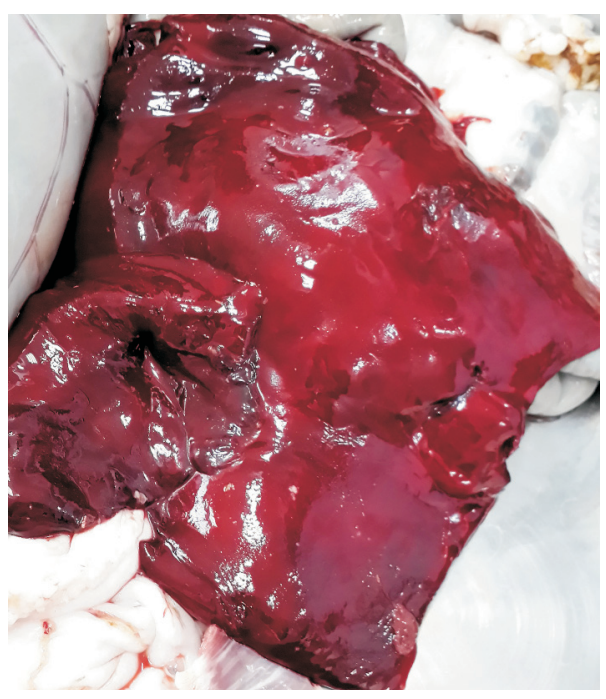

Fig. 4. Coagulated blood in the abdominal cavity

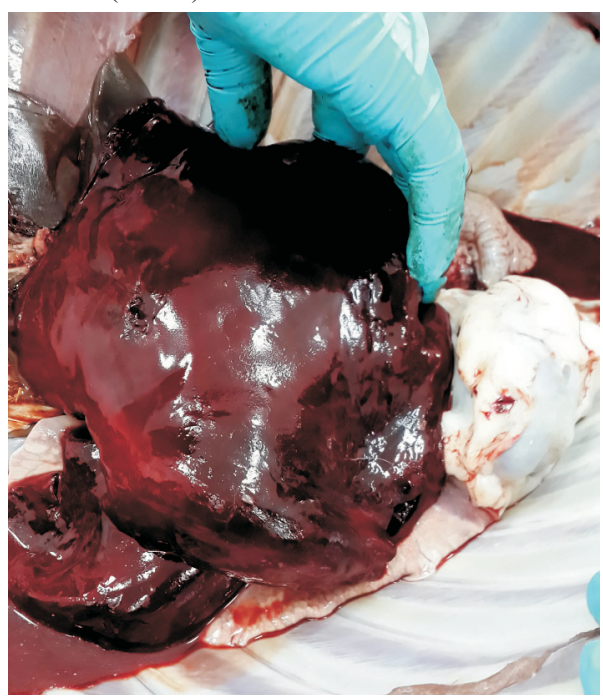

Fig. 5. Coagulated blood in the thorax 
A. Simsek et al.: Diaphragmatic hernia in a sheep

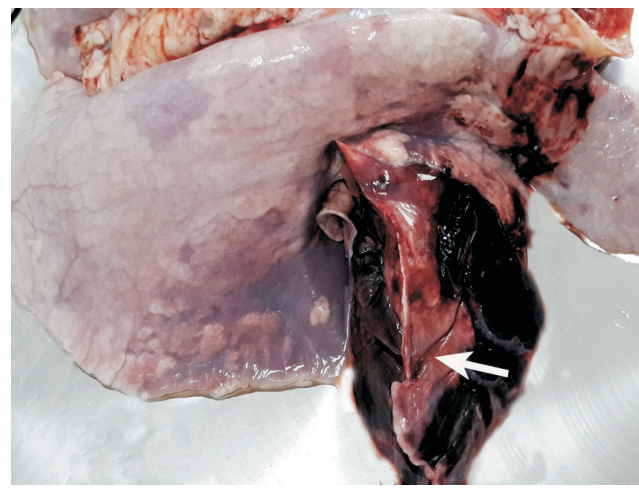

Fig. 6. Rupture of the right cranial lobe of the lung (arrow)

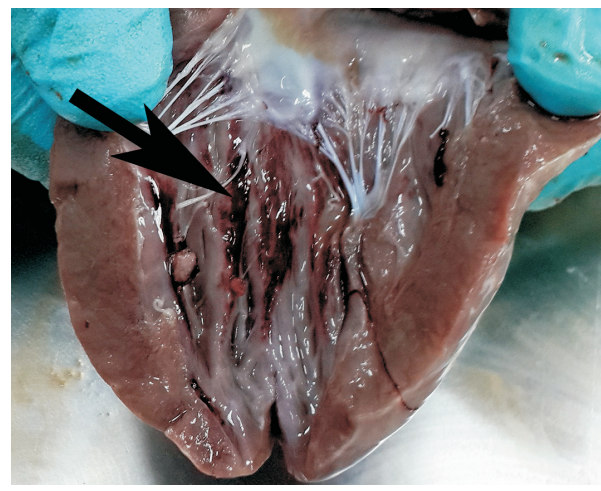

Fig. 7. Ecchimotic haemorrhages (arrows) on endocardium of left ventricle

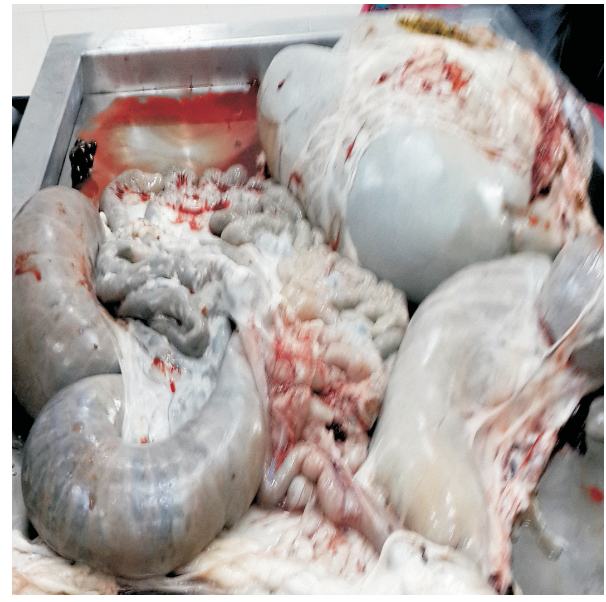

Fig. 8. The forestomach and caecal constipation

According to the haematological examination results, the total leukocyte count, erythrocyte count, haematocrit value and haemoglobin level were $14 \times 10^{3} / \mu \mathrm{L}$ (reference range $4-12 \times 10^{3} / \mu \mathrm{L}$ ), $8.5 \times 10^{6} / \mu \mathrm{L}$ (reference range $8-15 \times 10^{6} / \mu \mathrm{L}$ ), $27 \%$ (reference range $24-49 \%$ ) and $9.5 \mathrm{~g} / \mathrm{dL}$ (reference range $8-16 \mathrm{~g} / \mathrm{dL}$ ), respectively. Serum biochemical tests demonstrated that the levels of the enzymes aspartate aminotransferase $(379 \mathrm{IU} / \mathrm{L}$, reference range 49-123.3 IU/L), gamma-glutamyl transferase (57 IU/L, reference range 19.6-44.1 IU/L), creatine kinase (337 IU/L, reference range 7.7-101 IU/L) and lactate dehydrogenase (646 IU/L, reference range 83.1-475.6 IU/L) exceeded the upper reference 
limits, whilst the albumin $(1.95 \mathrm{~g} / \mathrm{dL}$, reference range $2.7-3.7 \mathrm{~g} / \mathrm{dL})$ and total protein $(5.77$ $\mathrm{g} / \mathrm{dL}$, reference range 5.9-7.8 $\mathrm{g} / \mathrm{dL}$ ) levels were below the lower reference limits. The other serum biochemical parameters investigated (calcium, phosphorus, glucose, direct bilirubin, total bilirubin, creatinine, sodium, potassium and chloride) were found to fall within the normal reference limits.

Due to the severe progression of respiratory failure during clinical examination, the animal was euthanized upon the request of the owner, and a necropsy was performed. At necropsy, it was observed that the left hepatic lobe had protruded into the thoracic cavity through a defect in the diaphragm, which measured $4.5 \mathrm{~cm}$ in diameter, and that a diaphragmatic hernia had developed (Figs. 1 and 2). The left hepatic lobe presented with a rupture, which was $8-9 \mathrm{~cm}$ in length, $2-3 \mathrm{~cm}$ in width and $1 \mathrm{~cm}$ in depth, and was associated with haemorrhage due to tissue damage (Fig. 3). The amount of coagulated blood in the abdominal and thoracic cavities was approximately 100-200 mL and 500-600 $\mathrm{mL}$, respectively (Figs. 4 and 5). The cranioventral lobe of the right lung was determined to have ruptured, and there were petechial haemorrhages in the endocardium (Figs. 6 and 7). Other notable necropsy findings were constipation (Fig. 8) and the presence of parasitic cysts in the omentum.

\section{Discussion}

Diaphragmatic hernias are uncommon in farm animals (TAFTI, 1998). Traumatic hernias are caused by mechanical factors, such as pregnancy, dystocia, falls (BELLAVANCE et al., 2010) and traffic accidents (KORKMAZ et al., 2010). The anamnesis of the patient suggested that the animal had not been exposed to a traumatic condition such as a traffic accident or a fall from a height. However, on the basis of the ruptures observed in the liver and lungs, and the presence of blood in the thoracic and abdominal cavities, it was concluded that the hernia had developed as a result of trauma, most possibly due to the animal having been raised in an overcrowded environment.

Although the clinical signs that animals suffering from diaphragmatic hernia display vary with the size and location of the defect in the diaphragm, these animals generally present with dyspnoea, bilateral asymmetric lung sounds (NARAYANAN et al., 2014), anorexia, tachycardia, slightly increased body temperature, intestinal sounds upon the auscultation of the thorax, and constipation (IMREN and SAHAL, 1996). The animal which, according to the anamnesis, suffered from anorexia and constipation, was determined upon clinical examination to present with respiratory failure and weaker lung sounds on the right side of the body, in comparison to the left side. Due to constipation, the ruminal content was not able to be obtained with the probing of the rumen.

NARAYANAN et al. (2014) reported not to have determined any abnormality in the haematological or serum biochemical parameters of a goat kid that suffered from 
diaphragmatic hernia due to involvement in a traffic accident. In this case study, the increase in the total leukocyte count, revealed by haematological examination, was considered to be an indicator of the inflammation caused by trauma. Furthermore, as a result of haemorrhage, it was ascertained that the erythrocyte count, haematocrit value and haemoglobin level had all decreased to a level close to the lower reference limit. Damage to the hepatic tissue and diaphragm was determined to have caused an increase in the serum activity of the enzymes aspartate aminotransferase, gamma-glutamy transferase, creatine kinase, and lactate dehydrogenase. The increase observed in the serum albumin and total protein concentrations was also attributed to hepatic tissue damage.

Apart from the use of radiography and ultrasonography for diagnostic purposes, diaphragmatic hernia cases are mostly diagnosed by laparotomy or on the basis of post-mortem examination (ZUSATZ et al., 2005; SABEV and KANAKOV, 2009). As the animal was euthanized upon the request of the owner due to the severe progression of respiratory failure during clinical examination, ultrasonographic and radiographic examinations were not performed and the diagnosis was based on post-mortem findings.

In conclusion, since diaphragmatic hernia is not common in sheep, anamnesis and clinical examination findings may not always suggest the occurrence of this condition. Therefore, it was concluded that sheep which present with anorexia, abdominal tympany, constipation and respiratory failure associated with bilateral asymmetrical lung sounds at clinical examination, and display increased aspartate aminotransferase, gamma-glutamyl transferase, creatine kinase and lactate dehydrogenase activity in the blood serum, should be further examined for the possibility of diaphragmatic hernia and internal organ damage.

\section{References}

BELlAVANCE, A., A. BONNEVILLE-HÉBERT, A. DESROCHERS, G. FECTEAU (2010): Surgical correction of a diaphragmatic hernia in a newborn calf. Can. Vet. J. 51, 767-769.

BUSIN, V., J. DEL POZO, N. SARGISON (2013): The diagnosis of diaphragmatic hernia in a 4-month-old Texel lamb. Livestock 18, 242-243.

IMREN, H. Y., M. SAHAL (1996): Veterinary Internal Medicine. $4^{\text {th }}$ ed. Medisan, Ankara, pp. 54.

KORKMAZ, M., Z. K. SARITAS, K. PAMUK (2010): Traumatic diaphragmatic hernia in a dog (a case report). Kocatepe Vet. J. 3, 51-54.

NARAYANAN, M. K., S. B. SARANGOM, C. B. DEVANAND, N. A. ANTONIA, J. JINU, K. P. GADHAFI, K. V. SYAM, S. ANOOP (2014): Diaphragmatic hernia in a kid - first case reported. Isr. J. Vet. Med. 69, 146-150.

RADOSTITS, O. M., C. C. GAY, K. W. HINCHCLIFF, P. D. CONSTABLE (2007): Veterinary Medicine: A Textbook of the Diseases of Cattle, Horses, Sheep, Pigs and Goats. $10^{\text {th }}$ ed. Saunders Elsevier, Edinburgh, p. 521. 
A. Simsek et al.: Diaphragmatic hernia in a sheep

SABEV, S. P., D. T. KANAKOV (2009): Diaphragmatic hernia in a horse - a case report. Vet. arhiv 79, 97-103.

TAFTI, A. K. (1998): Diaphragmatic hernia in a goat. Aust. Vet. J. 76, 166.

Williams, R. D., M. G. KATZ, A. S. FARGNOLI, A. P. KENDLE, K. L. MiHALKO, C. R. BRIDGES (2016): Bochdalek congenital diaphragmatic hernia in an adult sheep. Anat. Histol. Embryol. 45, 246-248.

ZUSATZ, M., C. DESBOIS, C. ROBERT, C. BIANCA (2005): Diaphragmatic hernia and rib fractures in an adult horse with signs of colic. Pferdeheilkunde 21, 420-422.

Received: 2 January 2017

Accepted: 18 May 2017

\section{SIMSEK, A., T. YAMAN, H. ICEN, A. KOCHAN: Dijafragmatska kila kod ovce- prikaz slučaja. Vet. arhiv 88, 271-277, 2018. \\ SAŽETAK}

Dvogodišnja ovca upućena je u klinike Zavoda za internu medicinu Veterinarskoga fakulteta Sveučilišta Dicle sa znakovima anoreksije, timpanije trbuha i zatvora. Klinički pregled životinje pokazao je otežano disanje povezano sa slabijim zvukovima pluća na desnoj strani u usporedbi s lijevom stranom tijela. Nije bilo ruminacija, a probadanjem stijenke buraga pomoću cijevi nije dobiven nikakav sadržaj. Životinja je eutanazirana na zahtjev vlasnika te je obavljena razudba kojom je opaženo da se lijevi jetreni režanj prostro u prsnu šupljinu kroz defekt u dijafragmi, i da se razvila dijafragmatska kila.

Ključne riječi: konstipacija; dijafragmatska kila; jetra; otežano disanje; ovca; trauma 
